\title{
Aquabacterium gen. nov., with description of Aquabacterium citratiphilum sp. nov., Aquabacterium parvum sp. nov. and Aquabacterium commune sp. nov., three in situ dominant bacterial species from the Berlin drinking water system
}

\author{
Sibylle Kalmbach, ${ }^{1}$ Werner Manz, ${ }^{1}$ Jörg Wecke ${ }^{2}$ and Ulrich Szewzyk ${ }^{1}$
}

1 Technische Universität Berlin, Institut für Technischen Umweltschutz, Fachgebiet Ökologie der

Mikroorganismen, D-10587

Berlin, Germany

2 Robert Koch-Institut, Nordufer 20, D-13353 Berlin, Germany
Author for correspondence: Werner Manz. Tel: +49 30314 25589. Fax: +493031473461. e-mail: manz0654@mailszrz.zrz.tu-berlin.de

\begin{abstract}
Three bacterial strains isolated from biofilms of the Berlin drinking water system were characterized with respect to their morphological and physiological properties and their taxonomic position. Phenotypically, the bacteria investigated were motile, Gram-negative rods, oxidase-positive and catalase-negative, and contained polyalkanoates and polyphosphate as storage polymers. They displayed a microaerophilic growth behaviour and used oxygen and nitrate as electron acceptors, but not nitrite, chlorate, sulfate or ferric iron. The substrates metabolized included a broad range of organic acids but no carbohydrates at all. The three species can be distinguished from each other by their substrate utilization, ability to hydrolyse urea and casein, cellular protein patterns and growth on nutrient-rich media as well as their temperature, $\mathrm{pH}$ and $\mathrm{NaCl}$ tolerances. Phylogenetic analysis, based on $16 \mathrm{~S}$ rRNA gene sequence comparison, revealed that the isolates are affiliated to the $\beta 1$-subclass of Proteobacteria. The isolates constitute three new species with internal levels of DNA relatedness ranging from 44.9 to $51.3 \%$. It is proposed that a new genus, Aquabacterium gen. nov., should be created, including Aquabacterium citratiphilum sp. nov., Aquabacterium parvum sp. nov. and Aquabacterium commune sp. nov. The type species of the new genus is Aquabacterium commune. The type strain of A. citratiphilum is strain B4 ${ }^{\top}$ (= DSM 11900'), the type strain of A. parvum is strain B6 (= DSM 11968') and the type strain of A. commune is strain B8' (= DSM 11901').
\end{abstract}

Keywords: drinking water, biofilms, Aquabacterium gen. nov.

\section{INTRODUCTION}

Drinking water and the related distribution networks represent distinct oligotrophic systems in which bacterial growth is severely limited by low contents of assimilatable organic carbon (LeChevallier et al., 1987; van der Kooij, 1992) and in some cases by phosphorus availability (Miettinen et al., 1996, 1997). In the past, the microbiology of drinking water systems has been studied almost exclusively from the point of

The GenBank accession numbers for the 165 rRNA sequences reported in this paper are AF035047-AF035054 (strains B1-B8, respectively). view of public health. Most studies have focused on the detection of bacterial species causing infectious diseases, such as Legionella pneumophila (Rogers \& Keevil, 1992; Rogers et al., 1994), opportunistic pathogens like Mycobacterium spp. (SchulzeRöbbecke \& Fischeder, 1989) or Aeromonas spp. (Kühn et al., 1997) and coliform bacteria as indicator organisms for faecal contamination (Christian \& Pipes, 1983; LeChevallier, 1990).

The autochthonous microbial population of this nutrient-deprived habitat, however, remains largely uncharacterized. A number of cultivation-based studies have attempted to describe the whole spectrum 
of bacterial species present in drinking water, commonly yielding bacteria affiliated to the genera Pseudomonas, Acinetobacter, Alcaligenes, Flavobacterium, Moraxella and Arthrobacter (LeChevallier et al., 1987; Rogers et al., 1994; Tall et al., 1995; Ward et al., 1986; Olson \& Nagy, 1984), but no information on the relevance and abundance of these organisms in their natural habitat could be gained. This is largely due to the lack of suitable cultivation approaches and, until recently, to the lack of appropriate methods to detect and monitor the in situ species composition of an ecosystem.

A number of bacterial strains isolated from biofilms of the Berlin drinking water distribution system were recently analysed by $16 \mathrm{~S}$ rRNA gene sequencing and the development and application of highly specific oligonucleotide probes (Kalmbach et al., 1997). In situ analysis of drinking water biofilms enabled the retrieval of these bacteria within their natural habitat and showed that three of the isolated strains, designated strains $\mathrm{B} 4^{\mathrm{T}}, \mathrm{B} 6^{\mathrm{T}}$ and $\mathrm{B} 8^{\mathrm{T}}$, dominated the biofilm population of the Berlin drinking water distribution system.

In the present study, these organisms are described by morphological and physiological characterization, DNA reassociation and $16 \mathrm{~S}$ rRNA-based phylogenetic classification. On the basis of these data, we propose a new genus, Aquabacterium gen. nov., with the description of Aquabacterium citratiphilum sp. nov. (type strain B4 ${ }^{\mathrm{T}}$, DSM $11900^{\mathrm{T}}$ ), Aquabacterium parvum sp. nov. (type strain B6 ${ }^{\mathrm{T}}$, DSM $11968^{\mathrm{T}}$ ) and Aquabacterium commune $\mathrm{sp}$. nov. (type strain $\mathrm{B} 8^{\mathrm{T}}$, DSM $11901^{\mathrm{T}}$ ). The type species of the new genus is Aquabacterium commune.

\section{METHODS}

Bacterial strains. Strains B1-B8 ${ }^{\mathrm{T}}$ were isolated in summer 1996 from biofilms grown on glass and polyethylene surfaces exposed in modified Robbins devices connected to a house installation system of the Berlin drinking water distribution network (Kalmbach et al., 1997). The temperature of the Berlin drinking water varied from 9.4 to $15.6^{\circ} \mathrm{C}$ and the $\mathrm{pH}$ ranged from $7 \cdot 2$ to $7 \cdot 7$. The bacteria were isolated on $\mathrm{R} 2 \mathrm{~A}$ agar (Reasoner \& Geldreich, 1985). The strains have been deposited with the DSMZ as DSM $11900^{\mathrm{T}}$ (strain $\mathrm{B} 4^{\mathrm{T}}$ ), DSM $11901^{\mathrm{T}}$ (strain B8 ${ }^{\mathrm{T}}$ ) and DSM $11968^{\mathrm{T}}$ (strain B6 ${ }^{\mathrm{T}}$ ).

Media and culture conditions. For cultivation of strains, R2A medium was modified by replacing starch with $0 \cdot 1 \%$ (v/v) Tween 80 (Sigma). Growth on nutrient-rich media was tested on nutrient agar, containing $3 \mathrm{~g}$ beef extract, $5 \mathrm{~g}$ peptone and $15 \mathrm{~g}$ agar $1^{-1}$ distilled water and on DEV nutrient agar (Anonymous, 1986). Oxidation of manganese was tested by growth on modified Rouf and Stokes medium (Wagner et al., 1994) as described by Spring et al. (1996). Unless specified otherwise, bacteria were grown in liquid medium with constant agitation (100 r.p.m.) at $20^{\circ} \mathrm{C}$.

Transmission electron microscopy. For negative-staining, samples of exponential-phase bacterial suspensions were dropped onto Piloform-coated copper grids. The material was negatively stained with a mixture of phosphotungstate $(2 \%, \mathrm{w} / \mathrm{v})$ and bacitracin $(0.005 \%, \mathrm{w} / \mathrm{v})$ according to Wolf et al. (1993) and examined with a Philips 400 electron microscope.

Thin sections of bacterial cells from exponential-phase cultures were prepared as described by Wolf et al. (1993). Fixation of the cells was carried out with $2.5 \%(\mathrm{v} / \mathrm{v})$ glutaraldehyde in $0.1 \mathrm{M}$ cacodylate buffer $(\mathrm{pH} \mathrm{7.2)}$ ) for at least $16 \mathrm{~h}$ at $4^{\circ} \mathrm{C}$. After washing with cacodylate buffer, the cells were post-fixed with $1.5 \%(\mathrm{w} / \mathrm{v})$ osmium tetroxide plus $1.65 \%(\mathrm{w} / \mathrm{v})$ potassium dichromate in $0.1 \mathrm{M}$ cacodylate buffer for $1 \mathrm{~h}$ at room temperature, dehydrated in a graded ethanol series and embedded in LR White (Science Services). Thin sections were cut with a Reichert OM U 3 ultramicrotome and post-stained for $6 \mathrm{~min}$ with $1 \%(\mathrm{w} / \mathrm{v})$ lead citrate. Examination of the thin sections was performed with a Philips 400 electron microscope.

SDSPAGE. Cells grown in liquid modified R2A medium were harvested by centrifugation at $10000 \mathrm{~g}$, resuspended in $50 \mu \mathrm{l}$ $2 \times$ SDS-gel-loading buffer $[100 \mathrm{mM}$ Tris $/ \mathrm{HCl}$, pH 6.8 , $200 \mathrm{mM}$ dithiothreitol, $4 \%$ (v/v) SDS, $0.2 \%$ (v/v) bromophenol blue, $20 \%(\mathrm{v} / \mathrm{v})$ glycerol] and lysed by boiling for 5 min. The extracts were separated on a gel containing $12 \%$ $(\mathrm{w} / \mathrm{v})$ polyacrylamide and stained with Coomassie blue according to standard procedures (Sambrook et al., 1989).

Morphological characteristics. Wet mounts of cells grown to exponential phase (approx. $10^{8}$ cells $\mathrm{ml}^{-1}$ ) in modified R2A medium were observed on agar-slides (Pfennig \& Wagener, 1986) by phase-contrast microscopy. Staining of polyalkanoate inclusion bodies with Nile blue A (Sigma) was performed as described by Ostle \& Holt (1982). Gramstaining was performed by using the Gram-colour kit from Merck. Colony morphology was determined by stereomicroscopy of cultures grown on modified R2A agar after $10 \mathrm{~d}$ incubation at $20^{\circ} \mathrm{C}$ in the dark.

Biochemical characteristics. The ability of the organisms to utilize different substrates was studied in mineral medium

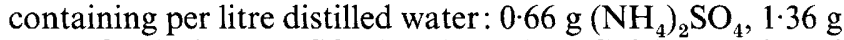
$\mathrm{KH}_{2} \mathrm{PO}_{4}, 0.123 \mathrm{~g} \mathrm{MgSO}_{4} .7 \mathrm{H}_{2} \mathrm{O}, 0.017 \mathrm{~g} \mathrm{CaSO}_{4} .2 \mathrm{H}_{2} \mathrm{O}$ and $0.006 \mathrm{~g} \mathrm{FeSO}_{4}$. The mineral medium was supplemented with autoclaved or filter-sterilized substrates (Table 1). Bacterial growth was determined for up to $7 \mathrm{~d}$ by measuring changes in the optical density $\left(\mathrm{OD}_{588}\right)$ with a Beckman spectrophotometer.

Cytochrome oxidase activity was determined with the Bacident Oxidase assay (Merck) and catalase production was determined by using a $3 \%(\mathrm{v} / \mathrm{v}) \mathrm{H}_{2} \mathrm{O}_{2}$ solution on colonies grown on modified R2A agar. DNA hydrolysis was examined by using commercially available DNase agar (Oxoid) and flooding of the plates with $1 \mathrm{M} \mathrm{HCl}$ after growth of the colonies. Aesculin hydrolysis was determined in liquid modified R2A medium supplemented with $0.01 \%$ $(\mathrm{w} / \mathrm{v})$ aesculin and $0.05 \%(\mathrm{w} / \mathrm{v})$ iron(III) citrate. Hydrolysis of urea was determined in liquid modified R2A medium containing $2 \%(\mathrm{w} / \mathrm{v})$ urea and $0.001 \%(\mathrm{w} / \mathrm{v})$ phenol red, inoculated with approximately $10^{8}$ cells. Hydrolysis of starch was determined on modified R2A agar containing $0.2 \%$ $(\mathrm{w} / \mathrm{v})$ soluble starch and no glucose by flooding of the plates with iodine solution (Merck). Hydrolysis of casein was tested on casein agar (double-strength, modified R2A agar was combined with an equal volume of sterile skimmed milk) by observation of clear zones around the colonies. The incubation period for catalase production and hydrolysis of DNA, aesculin, urea, starch and casein was $5 \mathrm{~d}$. Gelatin hydrolysis was determined by incubation for 6 weeks in modified liquid R2A medium supplemented with $12 \%(\mathrm{w} / \mathrm{v})$ gelatin. 
Table 1. Biochemical characteristics and substrate utilization of $A$. citratiphilum (B4), $A$. parvum (B6') and $A$. commune (B8 $\left.{ }^{\top}\right)$

\begin{tabular}{|c|c|c|c|}
\hline Characteristic & $\mathbf{B 4}^{\mathrm{T}}$ & B6 $^{\mathrm{T}}$ & $\mathbf{B 8}^{\mathrm{T}}$ \\
\hline Oxidase test & + & + & + \\
\hline Catalase reaction & - & - & - \\
\hline \multicolumn{4}{|l|}{ Reduction of: } \\
\hline $\mathrm{NO}_{3}^{-}$ & + & + & + \\
\hline $\mathrm{NO}_{2}^{-}, \mathrm{Fe}^{3+}, \mathrm{SO}_{4}^{2-}, \mathrm{ClO}_{3}^{-}$ & - & - & - \\
\hline \multicolumn{4}{|l|}{ Hydrolysis of: } \\
\hline Urea & + & + & - \\
\hline Casein & - & - & + \\
\hline Aesculin, DNA, starch, gelatin & - & - & - \\
\hline Temperature range $\left({ }^{\circ} \mathrm{C}\right)$ & $10-36$ & $14-34$ & $6-34$ \\
\hline $\mathrm{NaCl}$ concentration $(\% \mathrm{w} / \mathrm{v})$ & $0-1 \cdot 8$ & $0-0 \cdot 8$ & $0-0 \cdot 4$ \\
\hline $\mathrm{pH}$ range & $5 \cdot 5-10 \cdot 0$ & $6 \cdot 5-10 \cdot 0$ & $6 \cdot 5-9 \cdot 5$ \\
\hline \multicolumn{4}{|l|}{ Substrate utilization:* } \\
\hline Propionate, pyruvate, bromosuccinate & + & - & + \\
\hline Glycerol, lactate, citrate, $\gamma$-hydroxybutyrate & + & - & - \\
\hline Benzoate, Casamino acids, glutamate & - & - & + \\
\hline
\end{tabular}

*Substrates that were utilized by all three strains included Tweens 20, 40,60 and 80, acetate, butyrate, valerate, caproate, caprylate, succinate, adipate, pimelate, azelate, sebacate, fumarate, malate, butanol and $\beta$-hydroxybutyrate. Substrates that were not utilized by strains $\mathrm{B}^{\mathrm{T}}, \mathrm{B}^{\mathrm{T}}$ or $\mathrm{B}^{\mathrm{T}}$ included caprate, oxalate, formate, malonate, glutarate, phthalate, glyoxylate, tartrate, methanol, ethanol, D-glucose, L-arabinose, D-mannose, D-mannitol, D-maltose, D-fructose, D-xylose, D-ribose, L-rhamnose, D-lactose, D-galactose, D-trehalose, D-melibiose, D-ribulose, sucrose, $\mathrm{N}$-acetylglucosamine, gluconate, galacturonate and ascorbate. Substrate concentrations were $5 \mathrm{mM}$ except Casamino acids, which were used at $0 \cdot 1 \%(\mathrm{w} / \mathrm{v})$, and Tweens 20, 40,60 and 80, butanol and glycerol, which were used at $0 \cdot 1 \%(\mathrm{v} / \mathrm{v})$.

Reduction of nitrate and nitrite was determined chemically by inoculating freshly grown cultures in modified R2A medium containing $0 \cdot 17 \%$ agar supplemented with $0 \cdot 1$ $(\mathrm{w} / \mathrm{v}) \% \mathrm{KNO}_{3}$ or $0.02 \%(\mathrm{w} / \mathrm{v}) \mathrm{KNO}_{2}$, respectively. The cultures were grown for $5 \mathrm{~d}$ without agitation. The presence of nitrite was determined with equal volumes of $0.6 \%(\mathrm{w} / \mathrm{v})$ $N$-(1-naphthyl)ethylenediamine dihydrochloride in $5 \mathrm{M}$ acetic acid and $0.8 \%(\mathrm{w} / \mathrm{v})$ sulfanilic acid in $5 \mathrm{M}$ acetic acid, according to Neyra et al. (1977).

Electron acceptors. The potential use of different electron acceptors was studied in deep-agar cultures by inoculating $0.2 \mathrm{ml}$ freshly grown liquid cultures in $10 \mathrm{ml}$ liquefied and tempered $\left(41^{\circ} \mathrm{C}\right)$ modified $\mathrm{R} 2 \mathrm{~A}$ agar, containing $1.5 \%$ (w/v) agar and as electron acceptors: (i) atmospheric oxygen, (ii) $0 \cdot 1 \%\left(\mathrm{w} / \mathrm{v}\right.$ ) $\mathrm{KNO}_{3}$, (iii) $0.02 \%$ (w/v) $\mathrm{KNO}_{2}$, (iv) $10 \mathrm{mM} \mathrm{NaClO}_{3}$, (v) $10 \mathrm{mM} \mathrm{Na}_{2} \mathrm{SO}_{4}$ or (vi) $10 \mathrm{mM}$ iron(III) citrate. Fermentation capacity was tested in deep-agar cultures with modified R2A medium and in mineral medium containing $5 \mathrm{mM} \beta$-hydroxybutyrate. All cultures were grown under atmospheric conditions as well as $\mathrm{N}_{2}$ atmosphere $(99.99 \%)$ for $14 \mathrm{~d}$ and examined for visible colonies by using stereomicroscopy at $4 \times$ magnification.

The use of $\mathrm{SO}_{4}^{2-}$ or $\mathrm{Fe}^{3+}$ as electron acceptors was additionally examined under anaerobic conditions in a medium containing per litre distilled water: $1 \mathrm{~g} \mathrm{NaCl}, 0 \cdot 2 \mathrm{~g} \mathrm{~K}_{2} \mathrm{HPO}_{4}$, $0.27 \mathrm{~g} \mathrm{NH}_{4} \mathrm{Cl}, 0.41 \mathrm{~g} \mathrm{MgCl}_{2} .6 \mathrm{H}_{2} \mathrm{O}, 0.52 \mathrm{~g} \mathrm{KCl}$ and $0.15 \mathrm{~g}$ $\mathrm{CaCl}_{2} \cdot 2 \mathrm{H}_{2} \mathrm{O}$. After autoclaving, the medium was completed by adding $\left(\mathrm{l}^{-1}\right): 2 \cdot 5 \mathrm{~g} \mathrm{NaHCO}_{3}, 50 \mathrm{mg}$ vitamin $\mathrm{B}_{12}, 0.5 \mathrm{ml}$ vitamin solution (Adrian et al., 1998), $1 \mathrm{ml}$ trace elements solution (Adrian et al., 1998), $1 \mathrm{ml}$ selenite/tungstate solution (Tschech \& Pfennig, 1984), 0.5 mg resazurin as redox indicator and $0.4 \mathrm{~g} \mathrm{Na} \mathrm{Na}_{2} \mathrm{~S}$ as reducing agent. The medium was prepared under a $\mathrm{N}_{2} / \mathrm{CO}_{2}$ atmosphere $(80: 20$, $\mathrm{v} / \mathrm{v}$ ). Bacterial strains were inoculated in screw-cap bottles in an anaerobic medium supplemented with $0.1 \%$ Tween 80 as the sole carbon source. $\mathrm{Na}_{2} \mathrm{SO}_{4}$ or iron(III) citrate was added to a final concentration of $10 \mathrm{mM}$. The use of the electron acceptors was monitored by measuring cellular growth for a period of $14 \mathrm{~d}$ after incubation. Desulfovibrio desulfuricans (DSM 6949 ) was used as a positive control for iron and sulfate reduction in modified R2A deep-agar cultures and in the anaerobic medium.

Physiological characteristics. $\mathrm{NaCl}, \mathrm{pH}$ and temperature tolerance ranges were determined in modified $\mathrm{R} 2 \mathrm{~A}$ medium. Growth at various $\mathrm{NaCl}$ concentrations ranging from 0.2 to $2 \%(\mathrm{w} / \mathrm{v})$ and $\mathrm{pH}$ values ranging from 5.0 to 10.5 were determined spectroscopically $\left(\mathrm{OD}_{588}\right)$ over a period of $5 \mathrm{~d}$. To determine growth at different $\mathrm{pH}$ values, the modified R2A medium was supplemented with $10 \mathrm{mM}$ Bis-Tris buffer for $\mathrm{pH}$ 5-6.5 and with $10 \mathrm{mM}$ CAPS buffer for $\mathrm{pH} 9.0-10.5$; the $\mathrm{pH}$ was adjusted with $\mathrm{HCl}$ and $\mathrm{NaOH}$. Growth at temperatures ranging from 4 to $40^{\circ} \mathrm{C}$ was determined spectroscopically in modified R2A medium after 4,7 and $14 \mathrm{~d}$ incubation of static cultures.

165 rRNA-based phylogenetic analysis. Extraction of genomic DNA and amplification and sequencing of the $16 \mathrm{~S}$ rRNA genes from the strains investigated was performed as described previously (Kalmbach et al., 1997). The 16S rRNA sequences (Escherichia coli positions 50-1350) were aligned 



Fig. 1. (a)-(c) Phase-contrast micrographs of (a) A. citratiphilum (B4 $\left.4^{\top}\right)$, (b) A. parvum $\left(B 6^{\top}\right)$ and (c) $A$. commune (B8 $)$. Bar, $10 \mu \mathrm{m}$. (d)-(f) Transmission electron micrographs of (d) A. citratiphilum, (e) A. parvum and (f) A. commune. Typical cell morphologies of the three species, showing polyphosphate (black) and large polyalkanoate inclusion bodies (white). The cells are embedded in fibrillar matrix material. Bar, $1 \mu \mathrm{m}$.

using the Aligner tool of the ARB software package (Strunk \& Ludwig, 1995) and corrected manually according to primary and secondary structure similarity. Distance matrices were calculated from the completely aligned sequences and corrected for multiple base changes at single positions by the method of Jukes \& Cantor (1969). Phylogenetic trees were constructed by the neighbour-joining method of Saitou \& Nei (1987).

DNA-DNA hybridization. Isolation of genomic DNA and
DNA-DNA hybridization was performed at the DSMZ DNA was isolated and purified by chromatography on hydroxyapatite (Cashion et al., 1977) and DNA hybridization was performed as described by De Ley $e t$ al. (1970), by using a Gilford System 2600 spectrophotometer equipped with a Gilford 2527-R thermal programmer and plotter.

DNA base composition. The $\mathrm{G}+\mathrm{C}$ content of strains $\mathrm{B} 4^{\mathrm{T}}$, $\mathrm{B}^{\mathrm{T}}$ and $\mathrm{B} 8^{\mathrm{T}}$ was determined by HPLC at the DSMZ. 


\section{RESULTS}

\section{Cell and colony morphology}

Individual cells of strains $\mathrm{B} 4^{\mathrm{T}}, \mathrm{B} 6^{\mathrm{T}}$ and $\mathrm{B} 8^{\mathrm{T}}$ were motile, Gram-negative rods. They occurred as single cells, but tended to form cell aggregates. The cells of all three strains contained dark inclusion bodies visible by phase-contrast microscopy (Fig. 1), which could be identified as polyalkanoate storage polymers by staining with the fluorescent dye Nile blue A. Electron micrographs of thin sections of strains $B 4^{\mathrm{T}}, \mathrm{B} 6^{\mathrm{T}}$ and $\mathrm{B} 8^{\mathrm{T}}$ demonstrated the presence of polyalkanoate and polyphosphate inclusion bodies and mesosome-like structures as well as fibrillar matrix material surrounding the cells (Fig. 1). The cells were motile by means of a single polar flagellum, which was one to two times the length of the bacterium (Fig. 2). Strains $\mathrm{B} 4^{\mathrm{T}}$ and $\mathrm{B} 8^{\mathrm{T}}$ were $2-4 \mu \mathrm{m}$ long and about $0.5 \mu \mathrm{m}$ in diameter and strain $\mathrm{B} 6^{\mathrm{T}}$ was $1-2 \mu \mathrm{m}$ long and $0.5 \mu \mathrm{m}$ in diameter. When streaked onto modified R2A agar plates and incubated for $10 \mathrm{~d}$, strain $\mathrm{B} 4^{\mathrm{T}}$ formed cream-white, flat colonies with a smooth margin and a diameter of $2-3 \mathrm{~mm}$. Strain $\mathrm{B}^{\mathrm{T}}$ formed flat colonies with a smooth margin and a diameter of $1.5-2 \mathrm{~mm}$, which were white in the centre and transparent at the edges. Strain $\mathrm{B}^{\mathrm{T}}$ formed transparent, flat colonies that had a smooth margin and were $1.5-2 \mathrm{~mm}$ in diameter. When grown on modified Rouf and Stokes medium, colonies of strains $\mathrm{B} 4^{\mathrm{T}}, \mathrm{B} 6^{\mathrm{T}}$ and $\mathrm{B} 8^{\mathrm{T}}$ were

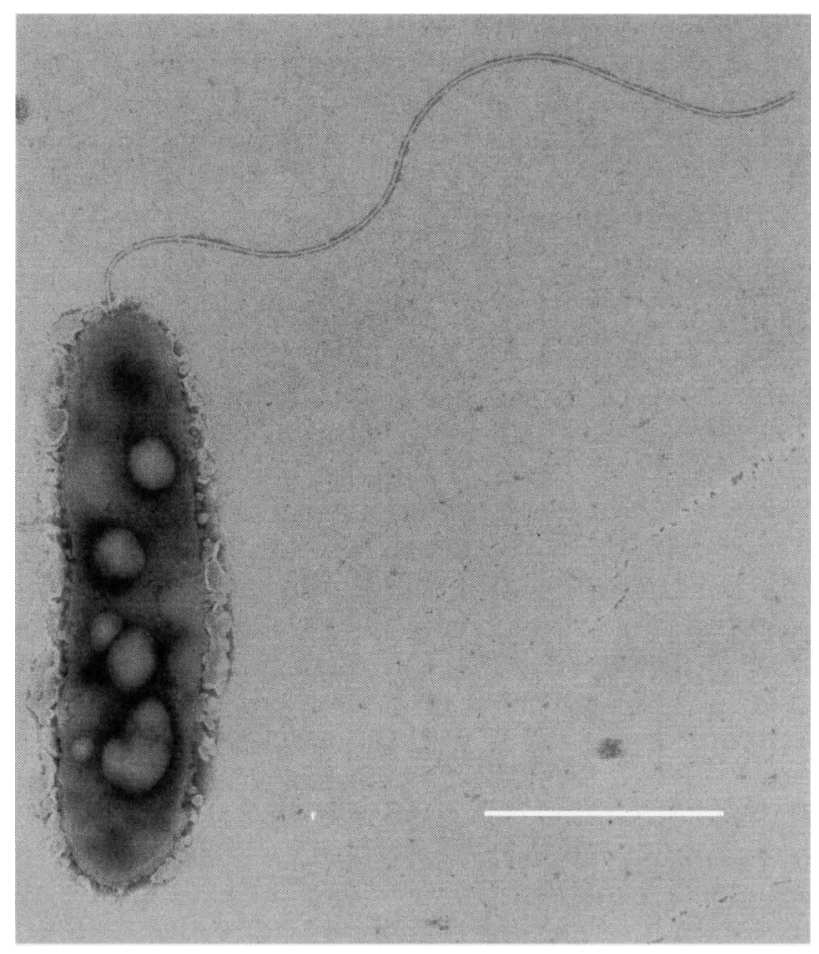

Fig. 2. Transmission electron micrograph of a negatively stained cell of $A$. citratiphilum $\left(B 4^{\top}\right)$, showing the polar inserted flagellum and polyalkanoate inclusion bodies. Bar, $1 \mu \mathrm{m}$.

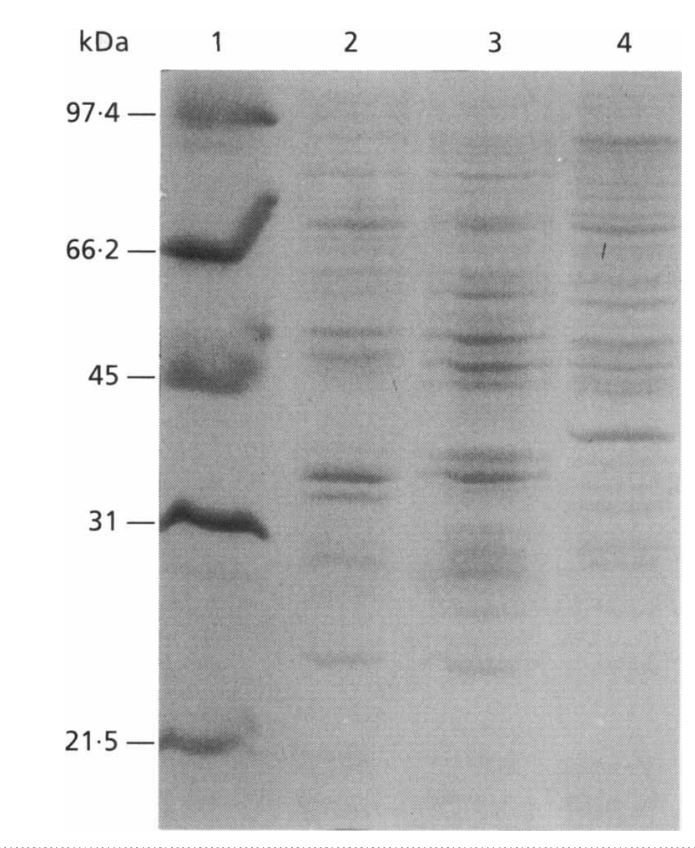

Fig. 3. Cellular protein patterns after SDS-PAGE of whole-cell extracts of $A$. citratiphilum $\left(B 4^{\top}\right)$ (lane 2$), A$. parvum $\left(B 6^{\top}\right)$ (lane 3 ) and $A$. commune ( $\mathbf{B 8}^{\mathrm{T}}$ ) (lane 4). Molecular masses of standards (lane 1) are indicated (in $\mathrm{kDa}$ ) on the left.

white, indicating that manganese oxidation did not occur.

\section{Growth conditions}

Strain $\mathrm{B} 4^{\mathrm{T}}$ grew well in liquid as well as on solid R2A medium, whereas strains $\mathrm{B} 6^{\mathrm{T}}$ and $\mathrm{B} 8^{\mathrm{T}}$ produced small colonies on R2A agar but did not grow well in liquid R2A medium. Based on the results of initial substrate utilization tests, R2A medium was modified by replacing starch with $0 \cdot 1 \%(\mathrm{v} / \mathrm{v})$ Tween 80 , resulting in improved growth of all strains investigated on solid as well as liquid medium. Strain B4 ${ }^{\mathrm{T}}$ was the only strain that grew well on nutrient-rich media. Strain $\mathrm{B}^{\mathrm{T}}$ produced tiny colonies $(0.1 \mathrm{~mm}$ diameter $)$, whereas strain $B 8^{\mathrm{T}}$ did not grow at all after $5 \mathrm{~d}$ incubation on nutrient-rich media. The temperature, $\mathrm{pH}$ and $\mathrm{NaCl}$ range for growth of the strains investigated is given in Table 1 .

\section{Metabolic properties}

The physiological properties of strains $\mathrm{B} 4^{\mathrm{T}}, \mathrm{B} 6^{\mathrm{T}}$ and $\mathrm{B} 8^{\mathrm{T}}$ are summarized in Table 1 . Strains $\mathrm{B} 4^{\mathrm{T}}, \mathrm{B} 6^{\mathrm{T}}$ and $\mathrm{B} 8^{\mathrm{T}}$ are aerobic, oxidase-positive and catalase-negative bacteria. When grown in deep-agar cultures, strains $\mathrm{B} 4^{\mathrm{T}}, \mathrm{B} 6^{\mathrm{T}}$ and $\mathrm{B} 8^{\mathrm{T}}$ displayed a microaerophilic growth behaviour, indicated by growth of the organisms in the form of a disc, typically located $2 \mathrm{~mm}$ below the agar surface. None of the strains could grow by fermentation in modified R2A agar or in mineral medium with $\beta$-hydroxybutyrate as the sole carbon source. For strains $B 6^{T}$ and $B 8^{T}$, nitrate reduction could be 


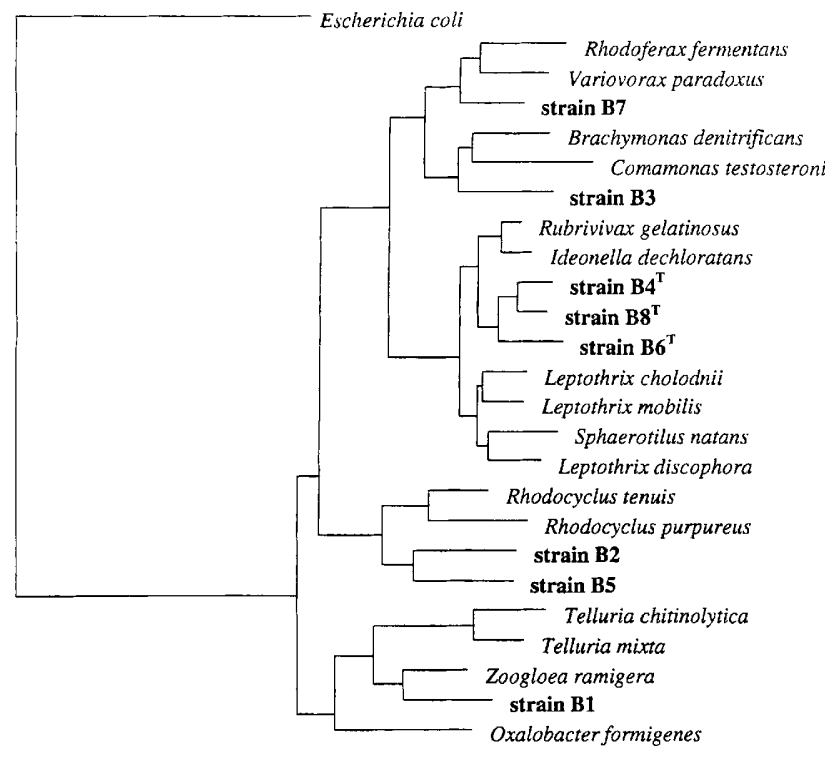

0.10

Fig. 4. Phylogenetic tree inferred from 16S rRNA gene sequences (at least 1300 bases), reflecting the relationships of A. citratiphilum (B4 ${ }^{\top}, \mathrm{DSM}^{1} 1900^{\top}$; accession no. AF035050), A. parvum (B6 ${ }^{\top}, \mathrm{DSM} 11968^{\top}$; $\mathrm{AF035052)}$ and $A$. commune $\left(\mathrm{B}^{\top}{ }^{\top}\right.$, DSM $11901^{\top}$; AF035054) to their closest known relatives and to the drinking water biofilm isolates B1 (AF035047), B2 (AF035048), B3 (AF035049), B5 (AF035051) and B7 (AF035053). Distance matrices were constructed from the aligned sequences and corrected for multiple base changes at single positions by the method of Jukes \& Cantor (1969) and a phylogenetic tree was constructed by the neighbour-joining method of Saitou \& Nei (1987) by using the ARB software package (Strunk \& Ludwig, 1995). Bar represents 10 nucleotide substitutions per 100 nucleotides.

demonstrated chemically as well as by growth in deepagar cultures, both under atmospheric conditions as well as an $\mathrm{N}_{2}$ atmosphere. Strain $\mathrm{B} 4^{\mathrm{T}}$ displayed only weak production of nitrite from nitrate in the chemical assay but was able to produce visible growth in deepagar cultures with nitrate as the sole electron acceptor. None of the strains reduced nitrite or chlorate, nor were sulfate or iron(III) utilized as electron acceptors in deep-agar cultures or liquid medium.

Starch, aesculin, gelatin and DNA were not hydrolysed by strains $\mathrm{B} 4^{\mathrm{T}}, \mathrm{B} 6^{\mathrm{T}}$ and $\mathrm{B} 8^{\mathrm{T}}$. Strain $\mathrm{B} 8^{\mathrm{T}}$ was the only strain able to hydrolyse casein and to grow with amino acids from casein hydrolysis or with glutamate as the sole carbon source (Table 1). Urea was hydrolysed by strains $B 4^{T}$ and $B 6^{T}$ but not by strain $B 8^{T}$. The substrates utilized by strains $\mathrm{B} 4^{\mathrm{T}}, \mathrm{B}^{\mathrm{T}}$ and $\mathrm{B} 8^{\mathrm{T}}$ are summarized in Table 1 . All three strains utilized fatty acids, carboxylic acids and alcohols but did not grow on any of the carbohydrates tested.

\section{Cellular protein analysis}

Protein patterns of strains $\mathrm{B} 4^{\mathrm{T}}, \mathrm{B}^{\mathrm{T}}$ and $\mathrm{B} 8^{\mathrm{T}}$ after separation by SDS-PAGE and staining with Coomassie blue are shown in Fig. 3. Although strains
Table 2. 165 rRNA gene sequence identity matrix for $A$. citratiphilum (B4 $)$, A. parvum (B6 ${ }^{\top}$ ) and $A$. commune (B8')

\begin{tabular}{|c|c|c|c|}
\hline \multirow[t]{2}{*}{ Taxon } & \multicolumn{3}{|c|}{$\begin{array}{l}\text { rRNA sequence } \\
\text { identity (\%) }\end{array}$} \\
\hline & $\mathbf{B 4}^{\mathrm{T}}$ & $\mathrm{B6}^{\mathrm{T}}$ & $\mathbf{B 8}^{\mathrm{T}}$ \\
\hline $\begin{array}{l}\text { Aquabacterium citratiphilum } \\
\left(\mathrm{B}^{\mathrm{T}} \mathrm{T}\right)\end{array}$ & - & - & - \\
\hline $\begin{array}{l}\text { Aquabacterium parvum } \\
\left(\mathrm{B}^{\mathrm{T}}\right)\end{array}$ & 96.5 & - & - \\
\hline $\begin{array}{l}\text { Aquabacterium commune } \\
\left(\mathrm{B} 8^{\mathrm{T}}\right)\end{array}$ & $98 \cdot 2$ & 97.2 & - \\
\hline $\begin{array}{l}\text { Ideonella dechloratans } \\
\text { (CCUG 30898 })\end{array}$ & $96 \cdot 4$ & $96 \cdot 7$ & $96 \cdot 6$ \\
\hline $\begin{array}{l}\text { Leptothrix cholodnii } \\
\text { (CCM } 1827=\text { LMG 7171) }\end{array}$ & $96 \cdot 7$ & $95 \cdot 3$ & $96 \cdot 5$ \\
\hline $\begin{array}{l}\text { Rubrivivax gelatinosus } \\
\left(\text { ATCC } 17011^{\mathrm{T}}\right)\end{array}$ & 95.7 & $96 \cdot 4$ & $95 \cdot 7$ \\
\hline $\begin{array}{l}\text { Leptothrix mobilis } \\
\left(\text { LMG } 17066^{\mathrm{T}}\right)\end{array}$ & $95 \cdot 5$ & 95.9 & $96 \cdot 1$ \\
\hline $\begin{array}{l}\text { Leptothrix discophora } \\
\text { (ATCC } 43182^{\mathrm{T}} \text { ) }\end{array}$ & $94 \cdot 4$ & 94.6 & $94 \cdot 4$ \\
\hline $\begin{array}{l}\text { Sphaerotilus natans } \\
\text { (accession no. Z18534) }\end{array}$ & $94 \cdot 9$ & $93 \cdot 7$ & $94 \cdot 6$ \\
\hline
\end{tabular}

$\mathrm{B} 4^{\mathrm{T}}, \mathrm{B} 6^{\mathrm{T}}$ and $\mathrm{B} 8^{\mathrm{T}}$ had some proteins in common, e.g. in the molecular mass range of 45 to $66 \mathrm{kDa}$, they exhibited a considerable heterogeneity in the range 31 to $45 \mathrm{kDa}$. Strains $\mathrm{B} 4^{\mathrm{T}}$ and $\mathrm{B} 6^{\mathrm{T}}$ share one common protein of about $35 \mathrm{kDa}$, which is not present in strain $\mathrm{B} 8^{\mathrm{T}}$, but each strain also displayed at least one distinct protein not present in either of the other two strains.

\section{S rRNA sequence analysis}

The almost complete 16S rRNA gene sequences (comprising 1429 nucleotides, E. coli positions 291458) of strains $\mathrm{B} 4^{\mathrm{T}}, \mathrm{B} 6^{\mathrm{T}}$ and $\mathrm{B} 8^{\mathrm{T}}$ have been determined in a previous study (Kalmbach et al., 1997). The phylogenetic tree shown in Fig. 4 reflects the relationships of strains $\mathrm{B} 4^{\mathrm{T}}, \mathrm{B} 6^{\mathrm{T}}$ and $\mathrm{B} 8^{\mathrm{T}}$ to their closest relatives and to additional bacterial strains (strains B1, B2, B3, B5 and B7) isolated from the same habitat. The three strains $\mathrm{B} 4^{\mathrm{T}}, \mathrm{B} 6^{\mathrm{T}}$ and $\mathrm{B} 8^{\mathrm{T}}$ form a monophyletic group within the $\beta 1$-subclass of Proteobacteria. Levels of $16 \mathrm{~S}$ rDNA sequence identity range from $98.2 \%$ between strains $\mathrm{B} 4^{\mathrm{T}}$ and $\mathrm{B} 8^{\mathrm{T}}$ to $97.2 \%$ between strains $\mathrm{B}^{\mathrm{T}}$ and $\mathrm{B} 8^{\mathrm{T}}$ and $96.5 \%$ between strains $\mathrm{B}^{\mathrm{T}}$ and $\mathrm{B} 4^{\mathrm{T}}$. The closest validly described relatives of strains $\mathrm{B} 4^{\mathrm{T}}, \mathrm{B} 6^{\mathrm{T}}$ and $\mathrm{B} 8^{\mathrm{T}}$ are represented by Ideonella dechloratans (CCUG $30898^{\mathrm{T}}$ ) and by Leptothrix cholodnii $(\mathrm{CCM} 1827=\mathrm{LMG} 7171)$; the corresponding identity values are given in Table 2 . Other close phylogenetic relationships were represented by 16S rDNA sequences of Rubrivivax gelatinosus (ATCC $17011^{\mathrm{T}}$ ), Leptothrix mobilis (GenBank accession no. X97071), Leptothrix disco- 
phora (ATCC 43182 ${ }^{\mathrm{T}}$ ) and Sphaerotilus natans (GenBank accession no. Z18534).

\section{DNA-DNA reassociation}

DNA-DNA hybridization studies revealed levels of relatedness between the investigated strains ranging from $44.9 \%$ (strains $\mathrm{B} 4^{\mathrm{T}}$ and $\mathrm{B} 8^{\mathrm{T}}$ ) to $45.4 \%$ for strains $\mathrm{B} 4^{\mathrm{T}}$ and $\mathrm{B} 6^{\mathrm{T}}$ and $51 \cdot 3 \%$ for strains $\mathrm{B} 6^{\mathrm{T}}$ and $\mathrm{B} 8^{\mathrm{T}}$.

\section{DNA base composition}

The $\mathrm{G}+\mathrm{C}$ content of the DNA of strain $\mathrm{B} 4^{\mathrm{T}}$ was 66 $\mathrm{mol} \%$, that of strain $\mathrm{B}^{\mathrm{T}}$ was $65 \mathrm{~mol} \%$ and that of strain $\mathrm{B}^{\mathrm{T}}$ was $66 \mathrm{~mol} \%$.

\section{DISCUSSION}

Three bacterial strains, termed $\mathrm{B} 4^{\mathrm{T}}, \mathrm{B} 6^{\mathrm{T}}$ and $\mathrm{B} 8^{\mathrm{T}}$, were recently shown to represent the predominant, frequent in situ bacterial species in biofilms obtained from the Berlin drinking water distribution system (Kalmbach et al., 1997). In the present study, the morphological and physiological properties as well as the phylogenetic affiliation of these strains were investigated. An analysis of phylogenetic relationships based on 16S rDNA sequence comparisons revealed that they constitute a cluster of bacteria affiliated to the $\beta 1$-subclass of Proteobacteria, located in the Rubrivivax-Leptothrix sub-branch of this taxonomic unit. DNA-DNA reassociations clearly showed that strains $\mathrm{B} 4^{\mathrm{T}}, \mathrm{B}^{\mathrm{T}}$ and $\mathrm{B} 8^{\mathrm{T}}$ represent three distinct bacterial species. The DNA base composition of strains $\mathrm{B} 4^{\mathrm{T}}, \mathrm{B} 6^{\mathrm{T}}$ and $\mathrm{B} 8^{\mathrm{T}}$, ranging from 65 to $66 \mathrm{~mol} \% \mathrm{G}+\mathrm{C}$, was similar to those of the closest phylogenetic relatives, Leptothrix cholodnii (68-70 mol \%) and Ideonella dechloratans $(68$ $\mathrm{mol} \%)$.

From a physiological perspective, the $\beta$-subclass of Proteobacteria is an extremely heterogeneous superfamily with few common features (De Ley, 1992). This is illustrated well by the closest validly described relatives of strains $\mathrm{B} 4^{\mathrm{T}}, \mathrm{B}^{\mathrm{T}}$ and $\mathrm{B} 8^{\mathrm{T}}$ : the phototrophic species Rubrivivax gelatinosus, the sheathed iron- and manganese-depositing genera Leptothrix and Sphaerotilus and the aerobic, chlorate-reducing bacterium Ideonella dechloratans. On the other hand, several of the phenotypic characteristics of strains B4 ${ }^{\mathrm{T}}$, $\mathrm{B} 6^{\mathrm{T}}$ and $\mathrm{B} 8^{\mathrm{T}}$ are typical of members of the $\beta$-subclass of Proteobacteria. In common with the majority of species of the $\beta$-Proteobacteria, the three strains investigated are aerobic bacteria that do not ferment. Furthermore, all three strains were unable to catabolize carbohydrates but grew well on fatty acids and carboxylic acids (Table 1). Additionally, the accumulation of polyalkanoate storage bodies is a widespread feature among members of the $\beta$-Proteobacteria and has been reported for the closely related genera Leptothrix and Sphaerotilus (Mulder \& Deinema, 1992).

Ideonella dechloratans and Leptothrix cholodnii, the closest phylogenetic neighbours of strains $\mathrm{B} 4^{\mathrm{T}}, \mathrm{B} 6^{\mathrm{T}}$ and $\mathrm{B}^{\mathrm{T}}$ (Table 2), are physiologically quite distinct from this cluster. Ideonella dechloratans is an aerobic, motile, chlorate-reducing bacterium isolated from activated sludge (Malmqvist et al., 1994). It clearly differs from strains $\mathrm{B} 4^{\mathrm{T}}, \mathrm{B} 6^{\mathrm{T}}$ and $\mathrm{B} 8^{\mathrm{T}}$ in its ability to reduce chlorate, to produce catalase, to metabolize carbohydrates and to grow at up to $42{ }^{\circ} \mathrm{C}$. Moreover, Ideonella dechloratans possesses two or more polar flagella. Leptothrix cholodnii is a manganese-oxidizing bacterium, characterized by the formation of darkbrown colonies on modified Rouf and Stokes medium, whereas strains $\mathrm{B} 4^{\mathrm{T}}, \mathrm{B} 6^{\mathrm{T}}$ and $\mathrm{B} 8^{\mathrm{T}}$ were unable to oxidize manganese. In contrast to strains $\mathrm{B} 4^{\mathrm{T}}, \mathrm{B} 6^{\mathrm{T}}$ and $\mathrm{B}^{\mathrm{T}}$, Leptothrix cholodnii is unable to metabolize malate, succinate, butyrate or fumarate but is able to metabolize carbohydrates (Spring et al., 1996).

As a common trait, strains $\mathrm{B} 4^{\mathrm{T}}, \mathrm{B} 6^{\mathrm{T}}$ and $\mathrm{B} 8^{\mathrm{T}}$ displayed a microaerophilic growth behaviour. Growth at low oxygen levels is also described for the LeptothrixSphaerotilus group, conferring a competitive advantage on these organisms in ecosystems such as sewage or activated sludge (Mulder \& Deinema, 1992). The microaerophilic growth behaviour is well suited for the anoxic conditions present in the groundwater used as the raw water source for the Berlin drinking water, where bacteria restricted to aerobic metabolism might not be able to proliferate. Although nitrate is not present in large amounts in the anoxic groundwater (typical nitrate concentrations ranged from 0.04 to $\left.1.33 \mathrm{mg} \mathrm{l}^{-1}\right)$, it presumably plays a role as an alternative electron acceptor. The predominance of strain $B 8^{\mathrm{T}}$ throughout the drinking water distribution system (Kalmbach et al., 1997) might be supported by its broader temperature range compared to the temperature range of strains $\mathrm{B} 4^{\mathrm{T}}$ and $\mathrm{B}^{\mathrm{T}}$, as well as by its greater nutritional versatility compared to that of strain $\mathrm{B} 6^{\mathrm{T}}$. With regard to their temperature requirements, all three strains grew at their lower growth limit.

We propose the description of the new genus, Aquabacterium gen. nov., containing three species, Aquabacterium citratiphilum sp. nov., Aquabacterium parvum sp. nov. and Aquabacterium commune sp. nov. $A$. commune is the type species of the new genus Aquabacterium.

\section{Description of Aquabacterium gen. nov.}

Aquabacterium (A.qua.bac'te.ri.um. L. n. aqua water; Gr. n. bakterion rod; Aquabacterium a rod-shaped bacterium, isolated from drinking water biofilms).

The three proposed new species, A. citratiphilum, $A$. parvum and $A$. commune, were isolated from a drinking water biofilm in a house installation system at the Technische Universität Berlin. All members of the genus are Gram-negative, rod-shaped bacteria and are motile by means of monotrichous flagella. They contain polyalkanoate and polyphosphate inclusion bodies and produce fibrillar matrix material. They are oxidase-positive, catalase-negative, display a micro- 
aerophilic growth behaviour and cannot grow by fermentation. Nitrate serves as an alternative electron acceptor, but not nitrite, chlorate, sulfate or iron(III). Manganese is not oxidized. All three species utilize Tweens 20,40,60 and 80, acetate, butyrate, valerate, capronate, caprylate, succinate, adipate, pimelate, azelate, sebacate, fumarate, $\beta$-hydroxybutyrate, malate and butanol. None of them utilizes any of the carbohydrates tested, nor is starch, aesculin, gelatin or DNA hydrolysed. The $\mathrm{G}+\mathrm{C}$ content of the DNA ranges from 65 to $66 \mathrm{~mol} \%$. The type species is Aquabacterium commune, since it is the most widespread species in drinking water system biofilms.

\section{Description of Aquabacterium commune sp. nov.}

Aquabacterium commune (com'mu.ne. L. adj. communis, -e common, referring to the predominance of the species in drinking water biofilms of the Berlin distribution system).

Cells are rods $(0.5 \times 2-4 \mu \mathrm{m})$ and possess a single, polar flagellum. Flat, transparent colonies with a smooth margin (1.5-2 $\mathrm{mm}$ diameter) are present after $10 \mathrm{~d}$ incubation at $20^{\circ} \mathrm{C}$ on modified $\mathrm{R} 2 \mathrm{~A}$ agar. The temperature range for growth is $6-34^{\circ} \mathrm{C}$. Growth occurs between $\mathrm{pH} 6.5$ and 9.5 and in the presence of $\mathrm{NaCl}$ at concentrations as high as $0.4 \%$. In addition to the substrates used by all members of the genus, $A$. commune utilizes propionate, bromosuccinate, pyruvate, benzoate, Casamino acids and glutamate. $A$. commune is able to hydrolyse casein but not urea. The $\mathrm{G}+\mathrm{C}$ content of the DNA is $66 \mathrm{~mol} \%$. Isolated from a drinking water house installation system. The type strain is strain $\mathrm{B} 8^{\mathrm{T}}\left(=\mathrm{DSM} 11901^{\mathrm{T}}\right)$.

\section{Description of Aquabacterium citratiphilum sp. nov.}

Aquabacterium citratiphilum (ci.tra.ti'phi.lum. L. n. citrus lemon tree; L. n. acidum acid; L. n. adj. acidum citri citric acid; Gr. adj. philos loving; M.L. n. adj. citratiphilum citrate-loving, referring to the preferred utilization of citrate as carbon and energy source).

Cells are rods $(0.5 \times 2-4 \mu \mathrm{m})$ and possess a single, polar flagellum. Flat, cream-white colonies with a smooth margin (2-3 mm diameter) are present after $10 \mathrm{~d}$ incubation at $20^{\circ} \mathrm{C}$ on modified $\mathrm{R} 2 \mathrm{~A}$ agar. The temperature range for growth is $10-36^{\circ} \mathrm{C}$. Growth occurs between $\mathrm{pH} 5.5$ and 10.0 and in the presence of $\mathrm{NaCl}$ up to $1.8 \%$. In addition to the substrates used by all members of the genus, $A$. citratiphilum utilizes propionate, bromosuccinate, pyruvate, lactate, citrate, $\gamma$-hydroxybutyrate and glycerol. $A$. citratiphilum is able to hydrolyse urea. The $\mathrm{G}+\mathrm{C}$ content of the DNA is $66 \mathrm{~mol} \%$. Isolated from a drinking water house installation system. The type strain is strain $B 4^{\mathrm{T}}$ $\left(=\right.$ DSM $\left.11900^{\mathrm{T}}\right)$.

\section{Description of Aquabacterium parvum sp. nov.}

Aquabacterium parvum (par'vum. L. adj. parvus small).
Cells are rods $(0.5 \times 1-2 \mu \mathrm{m})$ and possess a single, polar flagellum. Flat colonies with a smooth margin (1.5-2 $\mathrm{mm}$ diameter), which are white in the centre of the colony and transparent at the edges, are present after $10 \mathrm{~d}$ incubation at $20^{\circ} \mathrm{C}$ on modified R2A agar. The temperature range for growth is $14-34^{\circ} \mathrm{C}$. Growth occurs between $\mathrm{pH} 6.5$ and 10.0 and in the presence of $\mathrm{NaCl}$ up to $0.8 \%$. A parvum shows the substrate utilization typical for the genus Aquabacterium. A. parvum is able to hydrolyse urea. The $\mathrm{G}+\mathrm{C}$ content of the DNA is $65 \mathrm{~mol} \%$. Isolated from a drinking water house installation system. The type strain is strain $\mathrm{B}^{\mathrm{T}}$ $\left(=\right.$ DSM $\left.11968^{\mathrm{T}}\right)$.

\section{ACKNOWLEDGEMENTS}

We thank Robert Witzig for his excellent technical assistance.

\section{REFERENCES}

Adrian, L., Manz, W., Szewzyk, U. \& Görisch, H. (1998). Physiological characterization of a bacterial consortium reductively dechlorinating 1,2,3- and 1,2,4-trichlorobenzene. Appl Environ Microbiol 64, 496-503.

Anonymous (1986). Verordnung über Trinkwasser und über Wasser für Lebensmittelbetriebe. Bundesgesetzblatt Teil I, $760-773$.

Cashion, P., Holder-Franklin, M. A., McCully, J. \& Franklin, M. (1977). A rapid method for the base ratio determination of bacterial DNA. Anal Biochem 81, 461-466.

Christian, R. R. \& Pipes, W. O. (1983). Frequency distribution of coliforms in water distribution systems. Appl Environ Microbiol 45, 603-609.

De Ley, J. (1992). The Proteobacteria: ribosomal RNA cistron similarities and bacterial taxonomy. In The Prokaryotes, 2nd edn, pp. 2111-2140. Edited by A. Balows, H. G. Trüper, M. Dworkin, W. Harder \& K.-H. Schleifer. New York: Springer.

De Ley, J., Cattoir, H. \& Reynaerts, A. (1970). The quantitative measurement of DNA hybridization from renaturation rates. Eur J Biochem 12, 133-142.

Jukes, T. H. \& Cantor, C. R. (1969). Evolution of protein molecules. In Mammalian Protein Metabolism, pp. 21-132. Edited by H. N. Munro. New York: Academic Press.

Kalmbach, S., Manz, W. \& Szewzyk, U. (1997). Isolation of new bacterial species from drinking water biofilms and proof of their in situ dominance with highly specific $16 \mathrm{~S}$ rRNA probes. $\mathrm{Appl}$ Environ Microbiol 63, 4164-4170.

van der Kooij, D. (1992). Assimilable organic carbon as an indicator of bacterial regrowth. J Am Water Works Assoc 84, $57-65$.

Kühn, I., Allestam, G., Huys, G., Janssen, P., Kersters, K., Krovacek, K. \& Stenström, T.-A. (1997). Diversity, persistence, and virulence of Aeromonas strains isolated from drinking water distribution systems in Sweden. Appl Environ Microbiol 63, 2708-2715.

LeChevallier, M. W. (1990). Coliform regrowth in drinking water: a review. J Am Water Works Assoc 82, 74 86.

LeChevallier, M. W., Babcock, T. M. \& Lee, R. G. (1987). Examination and characterization of distribution system biofilms. Appl Environ Microbiol 53, 2714-2724.

Malmqvist, A., Welander, T., Moore, E., Ternström, A., Molin, G. \& Stenström, I.-M. (1994). Ideonella dechloratans gen. nov., sp. 
nov., a new bacterium capable of growing anaerobically with chlorate as an electron acceptor. Syst Appl Microbiol 17, 58-64.

Miettinen, I. T., Vartiainen, T. \& Martikainen, P. J. (1996). Contamination of drinking water. Nature 381, 654-655.

Miettinen, I. T., Vartiainen, T. \& Martikainen, P. J. (1997). Phosphorus and bacterial growth in drinking water. Appl Environ Microbiol 63, 3242-3245.

Mulder, E. G. \& Deinema, M. H. (1992). The sheathed bacteria. In The Prokaryotes, 2nd edn, pp. 2612-2624. Edited by A. Balows, H. G. Trüper, M. Dworkin, W. Harder \& K.-H. Schleifer. New York: Springer.

Neyra, C. A., Döbereiner, J., LaLande, R. \& Knowles, R. (1977). Denitrification by $\mathrm{N}_{2}$-fixing Spirillum lipoferum. Can $J$ Microbiol 23, 300-305.

Olson, B. H. \& Nagy, L. A. (1984). Microbiology of potable water. Adv Appl Microbiol 30, 73-132.

Ostle, A. G. \& Holt, J. G. (1982). Nile blue A as a fluorescent stain for poly- $\beta$-hydroxybutyrate. Appl Environ Microbiol 44, $238-241$.

Pfennig, N. \& Wagener, S. (1986). An improved method of preparing wet mounts for photomicrographs of microorganisms. J Microbiol Methods 4, 303-306.

Reasoner, D. J. \& Geldreich, E. E. (1985). A new medium for the enumeration and subculture of bacteria from potable water. Appl Environ Microbiol 49, 1-7.

Rogers, J. \& Keevil, C. W. (1992). Immunogold and fluorescein immunolabelling of Legionella pneumophila within an aquatic biofilm visualized by using episcopic differential interference contrast microscopy. Appl Environ Microbiol 58, 2326-2330.

Rogers, J., Dowsett, A. B., Dennis, P. J., Lee, J. V. \& Keevil, C. W. (1994). Influence of temperature and plumbing material selection on biofilm formation and growth of Legionella pneumophila in a model potable water system containing complex microbial flora. Appl Environ Microbiol 60, 1585-1592.
Saitou, N. \& Nei, M. (1987). The neighbor-joining method: a new method for reconstructing phylogenetic trees. Mol Biol Evol 4, $406-425$.

Sambrook, J., Fritsch, E. F. \& Maniatis, T. (1989). Molecular Cloning: a Laboratory Manual, 2nd edn. Cold Spring Harbor, NY: Cold Spring Harbor Laboratory.

Schulze-Röbbecke, R. \& Fischeder, R. (1989). Mycobacteria in biofilms. Zentrabl Hyg Umweltmed 188, 385-390.

Spring, S., Kämpfer, P., Ludwig, W. \& Schleifer, K.-H. (1996). Polyphasic characterization of the genus Leptothrix: new descriptions of Leptothrix mobilis sp. no. and Leptothrix discophora sp. no. nom. rev. and emended description of Leptothrix cholodnii emend. Syst Appl Microbiol 19, 634-643.

Strunk, O. \& Ludwig, W. (1995). ARB - a software environment for sequence data. Department of Microbiology, Technical University of Munich, Munich, Germany.

Tall, B. D., Williams, H. N., George, K. S., Gray, R. T. \& Walch, M. (1995). Bacterial succession within a biofilm in water supply lines of dental air-water syringes. Can J Microbiol 41, 647-654.

Tschech, A. \& Pfennig, N. (1984). Growth yield increase linked to caffeate reduction in Acetobacter woodii. Arch Microbiol 137, 163-167.

Wagner, M., Amann, R., Kämpfer, P., Assmus, B., Hartmann, A., Hutzler, P., Springer, N. \& Schleifer, K.-H. (1994). Identification and in situ detection of gram-negative filamentous bacteria in activated sludge. Syst Appl Microbiol 17, 405-417.

Ward, N. R., Wolfe, R. L., Justice, C. A. \& Olson, B. H. (1986). The identification of gram-negative, nonfermentative bacteria from water: problems and alternative approaches to identification. Adv Appl Microbiol 31, 293-365.

Wolf, V., Lange, R. \& Wecke, J. (1993). Development of quasimulticellular bodies of Treponema denticola. Arch Microbiol 160, 206-213. 